Article

\title{
Experimental Thermal Hazard Investigation of Pressure and EC/PC/EMC Mass Ratio on Electrolyte
}

\author{
Changcheng Liu ${ }^{1,2}$, Kaihui Zheng ${ }^{1}$, Yong Zhou ${ }^{3, *}$, Kai Zhu ${ }^{4}$ and Que Huang ${ }^{1,2, *(D)}$ \\ 1 School of Environment and Safety Engineering, North University of China, Taiyuan 030051, China; \\ ccliu@nuc.edu.cn (C.L.); khzheng2020@163.com (K.Z.) \\ 2 Institute of Advanced Energy Materials and Systems, North University of China, Taiyuan 030051, China \\ 3 State Key Laboratory of Fire Science, University of Science and Technology of China, Hefei 230026, China \\ 4 Business School, University of Shanghai for Science \& Technology, Shanghai 200093, China; \\ ishzhukai@usst.edu.cn \\ * Correspondence: yongz@ustc.edu.cn (Y.Z.); que.huang@nuc.edu.cn (Q.H.); Tel.: 86-186-5513-4511 (Y.Z.); \\ +86-155-2505-9957 (Q.H.)
}

check for updates

Citation: Liu, C.; Zheng, K.; Zhou, Y.; Zhu, K.; Huang, Q. Experimental Thermal Hazard Investigation of Pressure and EC/PC/EMC Mass Ratio on Electrolyte. Energies 2021, 14, 2511. https://doi.org/10.3390/ en14092511

Academic Editor: Wojciech Nowak

Received: 9 February 2021

Accepted: 16 April 2021

Published: 27 April 2021

Publisher's Note: MDPI stays neutral with regard to jurisdictional claims in published maps and institutional affiliations.

Copyright: (c) 2021 by the authors. Licensee MDPI, Basel, Switzerland. This article is an open access article distributed under the terms and conditions of the Creative Commons Attribution (CC BY) license (https:// creativecommons.org/licenses/by/ $4.0 /)$.

\begin{abstract}
Electrolytes are involved in the thermal runaway (TR) process of cells, which is a potential hazard in lithium-ion batteries (LIBs). Therefore, the effects of different mass ratio of carbonate solvents (ethylene carbonate (EC)/propylene carbonate (PC)/ethyl methyl carbonate (EMC)) with $\mathrm{LiBF}_{4}$ and different environmental pressure on the combustion characteristics of electrolyte such as flame centerline temperature, mass loss rate (MLR) and heat release rate (HRR) were analyzed. The combustion process could be divided into four stages: ignition, stable combustion stage, stable combustion with flame color change stage and extinguishing; with the decrease of pressure, the MLR of electrolyte declined and the combustion time prolonged, while the temperature of flame centerline increased.
\end{abstract}

Keywords: electrolyte; lithium-ion battery; mass ratio; environmental pressure; combustion characteristics

\section{Introduction}

Lithium-ion battery (LIB) is a rapidly developing chemical power supply. Compared with other secondary batteries, it is environmentally friendly and has characteristics of high energy density, high output voltage, high output power, small discharge, wide working temperature and no memory effect [1-3]. Since its invention, it has developed rapidly and successfully reached commercial application. However, with the large-scale application of LIBs, a large number of fire accidents have occurred in many application fields, especially in new energy vehicles (EVs), which has aroused the public's concern about the safety of LIBs.

The electrolyte, which moistens the electrodes and separator, so that lithium ions could be transmitted throughout the battery to achieve a normal charge-discharge cycle, plays an essential role in a battery [4-13]. The electrolyte is an ion transfer medium chosen to dissolve as much of the salt as possible and achieve as high a transference number of the desired ions as possible. However, volatile and flammable nature of the electrolyte is one of the critical factors that could cause the safety issues of LIBs [14]. In view of the flammability of electrolytes and its serious consequences, the thermal decomposition and combustion characteristics of electrolytes have been of wide concern to scholars all over the world in recent years. Eshetu et al. [15] explored the combustion characteristics of organic solvents and their mixtures used in electrolytes with different oxygen content. The experimental results showed that under the condition of sufficient oxygen content, the combustion of electrolyte would release a lot of heat, while the combustion under the insufficient oxygen content conditions would lead to more toxic gases. Fu et al. [16] compared the effects of pool fire diameter and radiation heat flux on the combustion characteristics of electrolytes. Their results indicated that the peak heat release rate (HRR) and mass loss rate (MLR) were directly proportional to the external radiation heat flux and inversely proportional to the 
pool fire diameter. Ribière et al. [17] studied the fire risk of commercial pouch cells by flame calorimetry and found that at least $50 \%$ of the combustion heat came from polymers, including electrolytes.

The previous studies were mainly carried out under atmospheric pressure, and there are few quantitative analysis studies about the safety and combustion characteristics of electrolytes in low-pressure and low-temperature environments such as plateaus and high altitude areas [18-36]. Therefore, in this paper, a commonly used lithium salt, $\mathrm{LiBF}_{4}$, was chosen as the solute, while three types of frequently-used carbonate solvents ethylene carbonate (EC), propylene carbonate (PC) and ethyl methyl carbonate (EMC) were selected as raw materials, so two kinds of electrolytes with different mixing mass ratios were prepared as the research objects in Anhui, Hefei (100.09 kPa), Lijiang, Yunnan (76.11 kPa) and Lhasa, Tibet $(65.23 \mathrm{kPa})$. In order to quantificationally analyze the safety of electrolyte reflecting as parameters including flame centerline temperature, radiant heat flux, HRR and MLR under low-pressure environment, the pool fire experiments of electrolyte were carried out.

The reason why we selected EC/PC/EMC mixtures is due to the demand of relative high dielectric constant and low viscosity for LIBs electrolyte, so solvents with high dielectric constant such as EC and PC are commonly chosen as parts of the components of electrolyte, but they also have high viscosity. Therefore, EC and PC were always mixed with solvents presenting a low dielectric constant and viscosity like EMC and diethyl carbonate (DEC) when forming the electrolyte mixture. In addition, EC-based electrolytes are some of the most popular solutions in current commercial LIBs. During the operation of a battery, EC could help generate a compact and stable solid electrolyte interphase (SEI) on the surface of graphitic carbon materials, which could prevent the further decomposition insertion of EC, thus protecting the graphite structure and guaranteeing the normal electrochemical performance of the electrodes [37,38]. However, the melting point of EC is relatively high $\left(36^{\circ} \mathrm{C}\right)$, so it does not show good low-temperature performance [39]. The melting point of $\mathrm{PC}$ is $-49^{\circ} \mathrm{C}$, which is much lower than that of EC. The electrical conductivity of PC is high, and it presents a good cryogenic property. Nevertheless, PC-based electrolytes indicate poor compatibility with graphic negative electrode materials as not only is the charge-discharge efficiency low, but they also obviously influence the reversible intercalation and stripping of Li-ions. The main reason is that PC can be thermally decomposed on the surface of graphite materials, so it cannot form a dense and effective SEI. By adding a film-forming additive, the consistency between PC and graphite materials could be improved, and the operating temperature range could be extended and widened for LIBs [40]. Thus, EC/PC/DMC mixture was chosen as the solvent in this study, which would be a potential electrolyte composition with good low-temperature properties.

The reason why $\mathrm{LiBF}_{4}$ was chosen as the lithium salt is based on the rules that an ideal lithium salt should show relative high solubility in the organic solvent, and properties such as a high thermal stability, good chemical durability and wide electrochemical window are necessary. Nowadays, a simple cation as the core and a Lewis acid as the stabilizer in complex anions are applied in common used lithium salts, such as $\mathrm{LiBF}_{4}, \mathrm{LiPF}_{6}, \mathrm{LiClO}_{4}$, $\mathrm{LiAsF}_{6}$. Among them, $\mathrm{LiBF}_{4}$ presents good ionic mobility. Even though the oxidation potential of $\mathrm{LiBF}_{4}$ is relatively low and it is not stable to heat or water, the cost is low, and it shows superior high-and-low temperature performance. In addition, the toxicity of $\mathrm{LiBF}_{4}$ is low, and its safety is high. Under the low-temperature condition in high altitude areas, selecting $\mathrm{LiBF}_{4}$ as the lithium salt in electrolyte helps improving the performance of LIBs.

The applicable scenario for this study is the electrolyte leakage from the battery. On the one hand, the electrolyte plays a significant role in LIBs since it is the component that could release most of the heat during the TR processing, and the energy of liquid electrolyte accounts a large part (at least 50\%) of the total energy for LIBs. Moreover, when an electrolyte is burning, the released heat is 2 to 3 times the stored electric energy. Thus, electrolytes are regarded as the main source of danger as a result of LIBs abuse [15]. On the other hand, during the TR process, electrolytes always show an injection from the inner battery, 
forming or generating flammable vapor, then causing fire or explosion accidents [41-55]. Golubkov et al. [43] investigated the composition of the gas released from a battery with an electrode of lithium cobalt oxide (LCO)/nickel-manganese-cobalt (NMC) with $100 \%$ state of charge (SOC) during TR process [43], which included a large amount of combustible gas generated by the decomposition of the electrolyte [44-46], as well as the vaporized electrolyte. In addition, there are a lot of reports pointing out that a jet fire would happen during the processing of TR. Ping et al. [47] studied the TR behavior of a 50 Ah battery with an electrode of lithium iron phosphate (LFP). The results showed that the TR process could be divided into six stages, including two jet flame phases. Huang et al. [48] found that the multiple jet fire stages might greatly increase the fire spread, and the ejected combustibles included vaporized electrolyte and flammable gases from the decomposition of the electrolyte or other reactions.

Therefore, in this study the electrolyte was chosen as the research object mainly concerning its burning characteristics when it leaks from LIBs, as this might give guidance to electrolyte manufacturers about the possible fire risk. In addition, quantitatively evaluating the fire risk of electrolyte should also help develop safer LIBs.

\section{Experimental Section}

\subsection{Samples and Materials}

In this paper, two kinds of electrolytes with different carbonate solvent ratios were prepared. The mass ratios of EC/PC/EMC were 12:38:50 and 38:12:50, respectively. $1 \mathrm{~mol} / \mathrm{L}$ $\mathrm{LiBF}_{4}$ was dissolved in the solvent. The combustion characteristics of the electrolytes under different pressure and mixing ratio were studied. The physical and chemical properties of the materials were listed in Tables 1 and 2, respectively. The percentages of water and hydrogen fluoride $(\mathrm{HF})$ in experimental samples were less than $0.002 \%$.

Table 1. Carbonate solvents used for thermal safety study in this paper.

\begin{tabular}{|c|c|c|c|c|c|c|c|c|c|c|}
\hline Name & $\begin{array}{l}\text { Chemical } \\
\text { Formula }\end{array}$ & $\begin{array}{c}\text { Melting } \\
\text { Point } \\
\left({ }^{\circ} \mathrm{C}\right)\end{array}$ & $\begin{array}{l}\text { Flash } \\
\text { Point } \\
\left({ }^{\circ} \mathrm{C}\right)\end{array}$ & $\begin{array}{c}\text { Boiling } \\
\text { Point }\left({ }^{\circ} \mathrm{C}\right)\end{array}$ & $\begin{array}{l}\text { Enthalpy of } \\
\text { Formation } \\
\text { (kJ/mol) }\end{array}$ & $\begin{array}{c}\text { Enthalpy } \\
\text { of Vapor- } \\
\text { ization } \\
\text { (kJ/g) }\end{array}$ & $\begin{array}{c}\text { Heat of } \\
\text { Combus- } \\
\text { tion } \\
(\mathrm{kJ} / \mathrm{g})\end{array}$ & $\begin{array}{l}\text { Autoignition } \\
\text { Temperature } \\
\left.{ }^{\circ} \mathrm{C}\right)\end{array}$ & $\begin{array}{l}\text { Driving } \\
\text { Factor } \mathrm{N}\end{array}$ & Chemical Structure \\
\hline EC & $\mathrm{C}_{3} \mathrm{H}_{4} \mathrm{O}_{3}$ & 36 & 145 & 248 & 52.67 & 0.62 & 12.38 & 465 & 13 & \\
\hline PC & $\mathrm{C}_{4} \mathrm{H}_{6} \mathrm{O}_{3}$ & -48.8 & 128 & 242 & 56.27 & 0.55 & 16.56 & 455 & 20 & \\
\hline EMC & $\mathrm{C}_{4} \mathrm{H}_{8} \mathrm{O}_{3}$ & -14 & 23 & 110 & 39.16 & 0.34 & 18.41 & 440 & $\backslash$ & \\
\hline
\end{tabular}

Table 2. Composition and parameters of the two electrolytes in this paper.

\begin{tabular}{|c|c|c|c|}
\hline Sample Number & Composition & Conductivity $\left(25^{\circ} \mathrm{C}, \mathrm{mS} / \mathrm{cm}\right)$ & Specific Gravity $\left(20^{\circ} \mathrm{C}, \mathrm{g} / \mathrm{cm}^{3}\right)$ \\
\hline Electrolyte 1 & $\begin{array}{c}1 \mathrm{~mol} / \mathrm{L} \text { of } \mathrm{LiBF}_{4} \text { dissolved in } \\
\mathrm{EC} / \mathrm{PC} / \mathrm{EMC} \text { with a mass } \\
\text { ratio of } 12: 38: 50\end{array}$ & 3.48 & 1.172 \\
\hline Electrolyte 2 & $\begin{array}{c}1 \mathrm{~mol} / \mathrm{L} \text { of } \mathrm{LiBF}_{4} \text { dissolved in } \\
\mathrm{EC} / \mathrm{PC} / \mathrm{EMC} \text { with a mass } \\
\text { ratio of } 38: 12: 50\end{array}$ & 4.03 & 1.201 \\
\hline
\end{tabular}

\subsection{Experimental Platform}

In this paper, the cone calorimeter based on oxygen consumption (OC) calorimetry was used to evaluate the combustion characteristics of electrolyte, and the important parameters such as HRR and MLR could be measured. Based on Thornton's principle [18,19], OC 
calorimetry is the most commonly used standard technique to measure heat release in a given fire dynamics. The HRR of combustion reaction could be estimated by the following Equation (1):

$$
\dot{q}=E\left(\dot{M}_{\mathrm{O}_{2}}^{0}-\dot{M}_{\mathrm{O}_{2}}\right)
$$

where $\dot{q}$ is the HRR of the measured material. $\dot{M}_{\mathrm{O}_{2}}^{0}$ is the mass flow rate (MFR) of $\mathrm{O}_{2}$ from the entrained air during the baseline measurement, while $\dot{M}_{\mathrm{O}_{2}}$ is that from the exhaust air duct during combustion process. $E$ is the empirical value, representing the heat released per unit mass of oxygen consumed, generally $13.1 \mathrm{~kJ} / \mathrm{g}$.

In this paper, a UW/UX series pallet electronic balance (Shimadzu, Kyoto, Japan) was used for mass measurements. Its accuracy is $0.01 \mathrm{~g}$, and the measurement range is from 0 to $6.4 \mathrm{~kg}$. The diameter of the circular oil pan is $10 \mathrm{~cm}$, and $25 \mathrm{~mL}$ electrolyte sample was taken for each combustion test. A fire-proof plate made of ceramic fiber was placed on the balance, then the sample pan was set on it, which could protect the measurement device from high temperature, obtaining relative accurate data, as shown in Figures 1 and 2. In order to ensure the consistency of experimental conditions in Hefei, Lijiang and Lhasa, the electrolyte was ignited directly by the same spark without external radiation heat flux. The temperature data was measured by K-type thermocouples and a type of 7018 temperature acquisition module. A radiative flux meter (STT-25-20, from Shanghai TecFront Electronics Corp. (Shanghai, China), whose response is $1.212 \mathrm{mV} /\left(\mathrm{kW} / \mathrm{m}^{2}\right)$ ) was applied to detect the radiation flux of flame, which was located $18 \mathrm{~cm}$ far from the fire centerline and $10 \mathrm{~cm}$ high from the sample pan. The experimental platform is shown in Figure 1, and the positions of thermocouples and radiation flux meter in Lhasa and Lijiang are presented in Figure 2. Each combustion experiment was repeated more than two times.

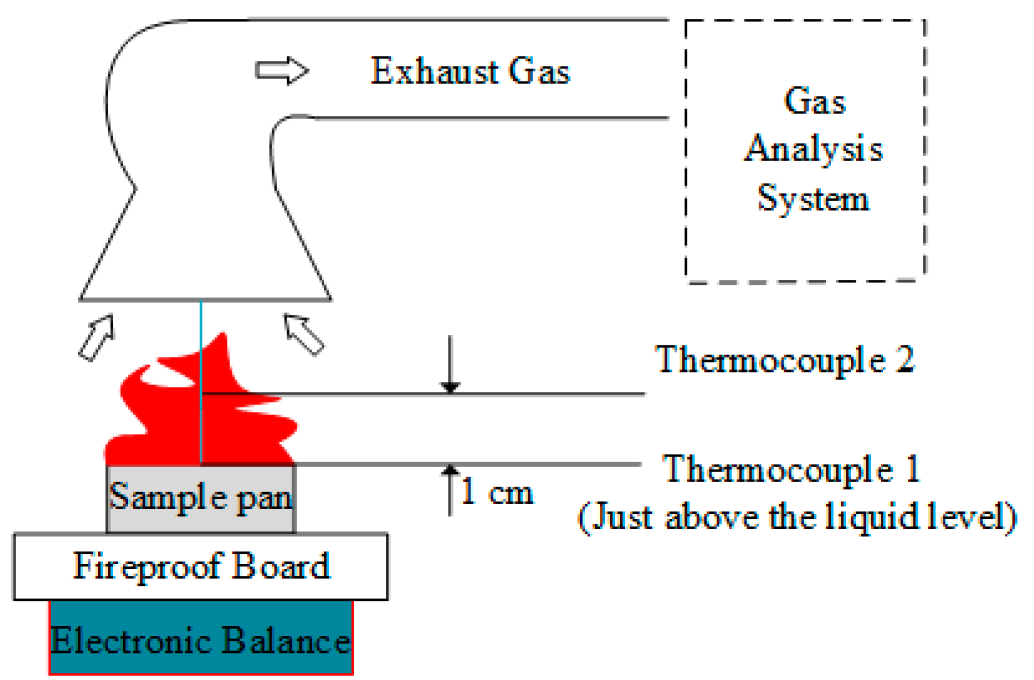

Figure 1. Structure diagram of the combustion platform including a cone calorimeter, with two thermocouples in Hefei (100.09 kPa). 
T7 $(20 \mathrm{~cm}$ above the liquid level)

T6 (16 $\mathrm{cm}$ above the liquid level)

T5 (12 $\mathrm{cm}$ above the liquid level)

T4 ( $8 \mathrm{~cm}$ above the liquid level)

Radiation

T3 (4 $\mathrm{cm}$ above the liquid level)

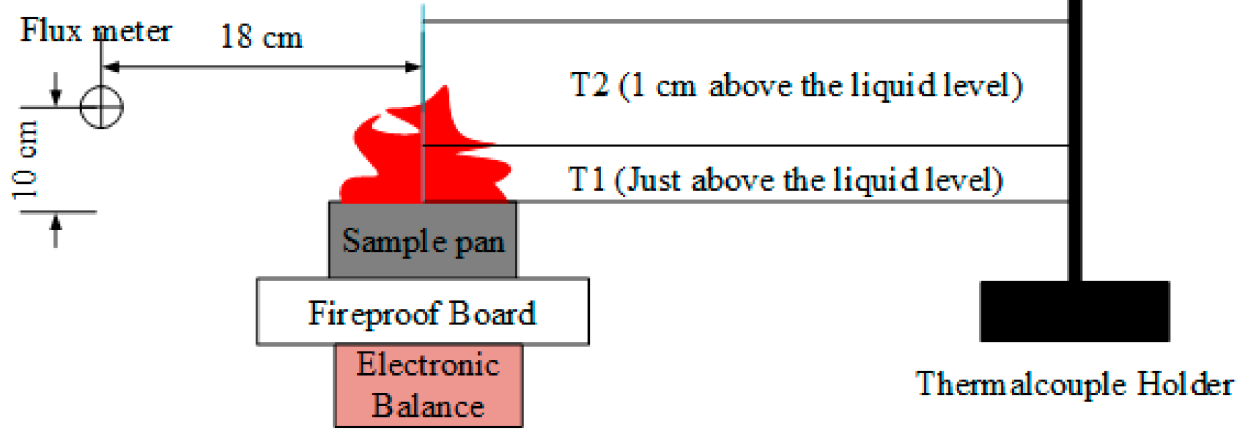

Figure 2. Positions of the thermocouples and radiation flux meter in Lijiang (76.11 kPa) and Lhasa $(65.23 \mathrm{kPa})$. Due to space limitations, only T1 and T2 were used in Hefei $(100.09 \mathrm{kPa})$.

\section{Results and Discussion}

\subsection{Combustion Process and Phenomena}

Table 3 summarizes the burning duration of two electrolytes in all the experimental locations, and Figure 3 presents the experimental phenomena of two electrolytes in Hefei and Lhasa. The combustion process of the two electrolytes were similar. First of all, the combustion process of both electrolytes could be divided into four stages: ignition, stable combustion stage, stable combustion with flame color change stage and extinguishing. Taking Electrolyte $1\left(1 \mathrm{~mol} / \mathrm{L}\right.$ of $\mathrm{LiBF}_{4}$ dissolved in EC/PC/EMC with a mass ratio of 12:38:50) as an example, after the ignitor ignited the combustible vapor above liquid, flame radiation accelerated the evaporation of electrolyte, and the electrolyte pool fire quickly entered a stable combustion stage, which took 5-10 s in Hefei. The stable combustion stage lasted for about $2 \mathrm{~min}$ and $30 \mathrm{~s}$. In this stage, the flame color was mainly yellow. Then it entered stable combustion with a flame color change stage, in which the flame height of electrolyte pool fire decreased and a small amount of visible green flame appeared at the bottom of the flame. The maintenance time of this phase was similar to that of stable combustion stage. Finally, the flame height decreased again, only a little beyond the top of the oil pan. In addition, the flame morphology was scattered around the oil pan. 
Table 3. Comparison of burning duration of two electrolytes in Hefei, Lijiang and Lhasa.

\begin{tabular}{ccc}
\hline & \multicolumn{2}{c}{ Burning Duration } \\
\cline { 2 - 3 } Combustion Location & Electrolyte 1 & Electrolyte 2 \\
& EC/PC/EMC & EC/PC/EMC \\
& $\mathbf{( 1 2 / 3 8 / 5 0 ~ w t )}$ & $\mathbf{( 3 8 / 1 2 / 5 0 ~ w t )}$ \\
\hline Hefei $(100.09 \mathrm{kPa})$ & $370 \mathrm{~s}$ & $377 \mathrm{~s}$ \\
Lijiang $(76.11 \mathrm{kPa})$ & $617 \mathrm{~s}$ & $652 \mathrm{~s}$ \\
Lhasa $(65.23 \mathrm{kPa})$ & $552 \mathrm{~s}$ & $562 \mathrm{~s}$ \\
\hline
\end{tabular}

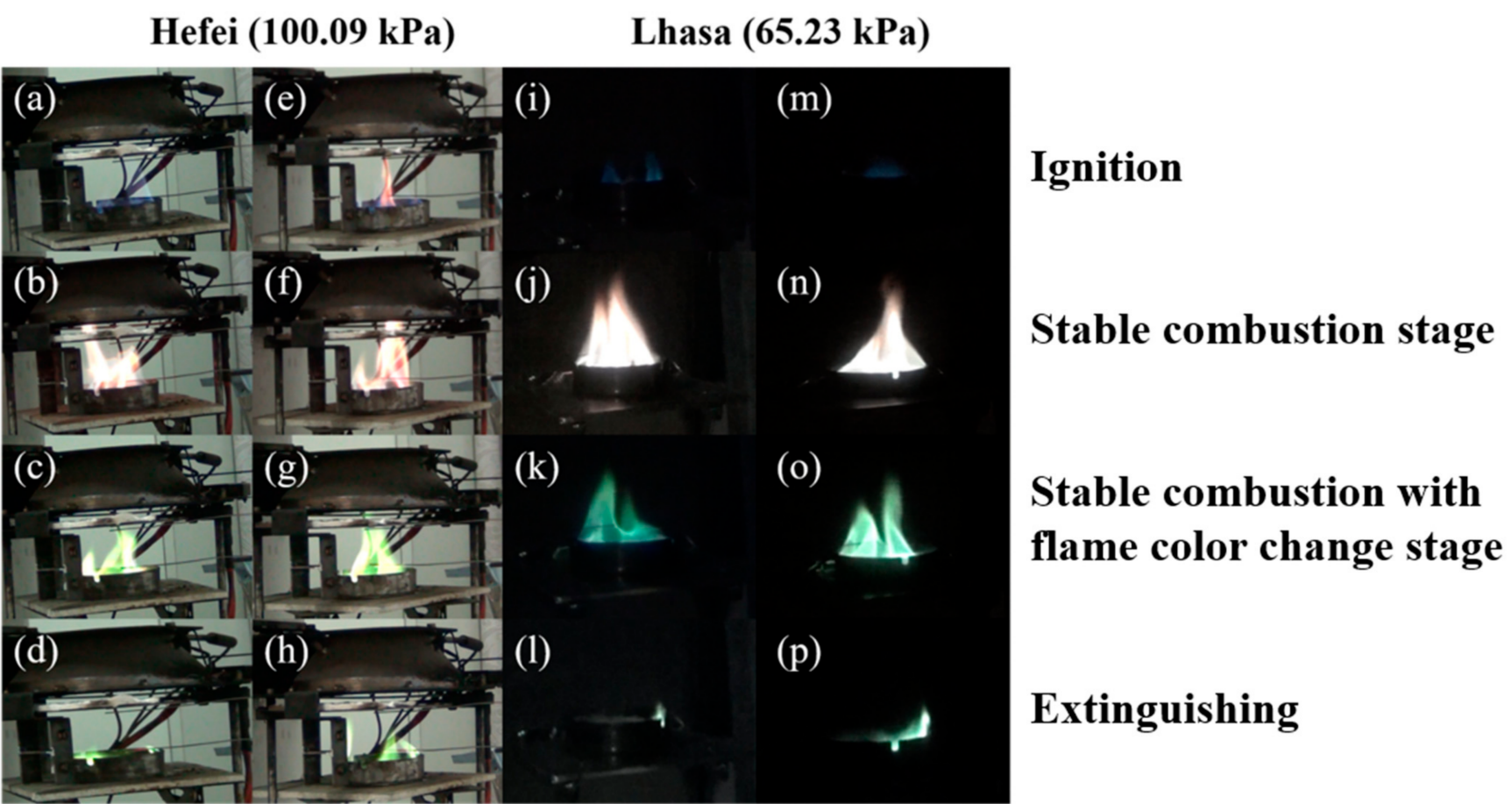

\section{Electrolyte 1 1 Electrolyte 2 $\quad$ Electrolyte 1 Electrolyte 2 \\ EC/PC/EMC EC/PC/EMC $(12 / 38 / 50 \mathrm{wt}) \quad(38 / 12 / 50 \mathrm{wt})$}

Figure 3. Experimental phenomena of two electrolytes in Hefei (100.09 kPa): (a-h) and Lhasa (65.23 kPa): (i-p).

Secondly, the flame color of stable combustion stage was mainly yellow. Thirdly, in Lijiang and Lhasa, where the air pressure is low, the burning duration of electrolyte pool fire was prolonged. In this study, the method to determine the stable combustion stage is to divide the electrolyte combustion stages by observing the change of electrolyte flame color and height.

However, there is a significant difference between the combustion phenomena of the two electrolytes: in the stable combustion with flame color change stage, the flame color of Electrolyte 1 pool fire was mainly yellow at first, accompanied by green flame at the bottom of the flame; in the final stage of combustion reaction, the flame color changed from yellow to green until the flame went out; while during stable combustion with flame color change stage, the flame of Electrolyte $2\left(1 \mathrm{~mol} / \mathrm{L}_{\text {of }} \mathrm{LiBF}_{4}\right.$ dissolved in EC/PC/EMC with a mass ratio of 38:12:50) pool fire was mainly green with a small amount of yellow flame. With the progress of combustion reaction, the flame color turned to green completely. Obviously, the presence of green flame is due to the participation of boron in the combustion process, indicating that the lithium salt $\left(\mathrm{LiBF}_{4}\right)$ was thermally decomposed and participated in the combustion process of the two electrolytes [56]. However, by observing the experimental 
phenomenon, the flame color of the two electrolyte samples was not the same in stable combustion with flame color change stage, and the main reason is that the solubility of $\mathrm{LiBF}_{4}$ was affected by the different carbonate mass ratio. During stable combustion stage, EMC might be basically completely consumed. According to the experimental results, the combustion phenomena of two electrolytes were obviously different. During the stable combustion stage, the flame color of Electrolyte 1 was mainly yellow at first, along with green flame at the bottom. In the final stage of combustion, the color of flame changed from yellow to green, till the extinguishing. In the stable combustion stage, the flame color of Electrolyte 2 was mostly green, with a small amount of yellow flame. During with the combustion reactions, the flame color turned to totally green. The time of flame color transition was determined by the solubility of $\mathrm{LiBF}_{4}$ in different solvents. Since the content of PC in Electrolyte 2 was lower, resulting in an advanced precipitation of $\mathrm{LiBF}_{4}$, which involved in the combustion, hence the flame color change time was earlier than that of Electrolyte 1.

\subsection{Mass Loss Rate}

Figure 4 shows the mass change and mass loss rate (MLR) curves of the two electrolytes in Hefei (100.09 kPa), Lijiang (76.11 kPa) and Lhasa (65.23 kPa), respectively, and MLR was obtained from the derivative of mass change data. By fitting the MLR curve, the period between the two intersection points of fitting line and MLR curve was regarded as the stable combustion stage and stable combustion with flame color change stage. As for the method of confirming the stable combustion stage for liquid pool fire, there are no accurate and precise operation steps in recent literatures.

On the basis of faithfulness and accuracy, a suite of operational steps and processes was proposed in this paper. Because that the combustion process of electrolyte in this work could be divided in three stages: ignition, stable combustion stage, and extinguishing, thus only determining the two key points when the ignition transformed to stable combustion stage, and that changed to extinguishing, respectively, then the stable combustion stage could be confirmed. Therefore, based on the mass loss data in Figure 3, at first a part of data in the middle stage were selected and linearly fitted to make sure the $R^{2}$ was above 0.99 , then the fitted line was lengthened, which would cross the MLR, and the two points of intersection would be regarded as the key points where the combustion status changed. The stage between the two points would be defined as the stable combustion stage, then through derivation the MLR could be obtained. According to the experimental phenomena, the overall stable combustion stage could be further divided into a "stable combustion stage" and a "stable combustion with flame color change stage", respectively. 


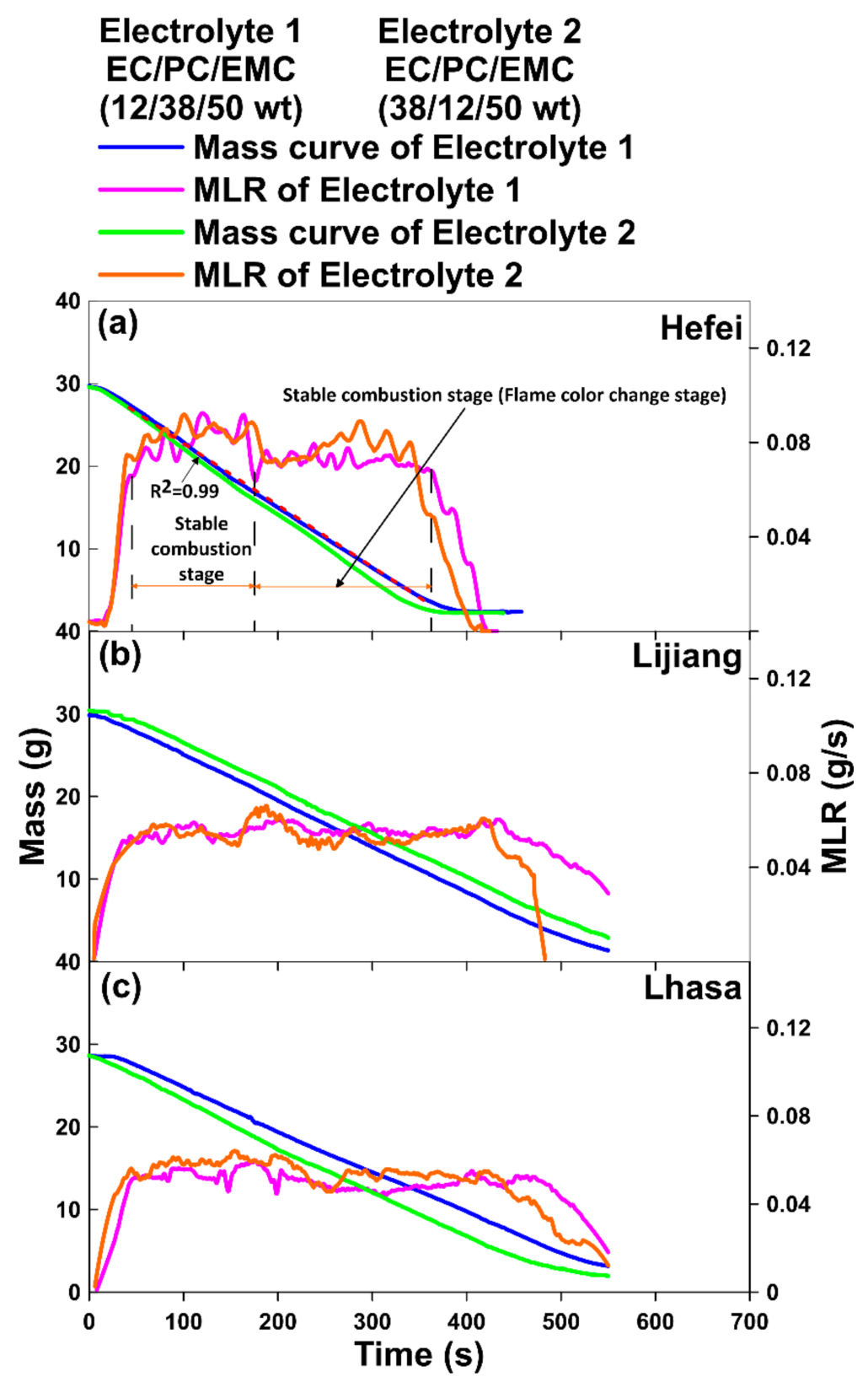

Figure 4. Mass change and MLR curves of two electrolytes in (a) Hefei (100.09 kPa), (b) Lijiang $(76.11 \mathrm{kPa})$ and $(\mathrm{c})$ Lhasa $(65.23 \mathrm{kPa})$.

It can be seen from Figure 4a that in Hefei, the change trend of MLR curve was consistent with the observed experimental phenomena. The combustion process could be divided into four stages: ignition, stable combustion stage, stable combustion with flame color change stage and extinguishing. However, the decline of environmental pressure would cause the decrease of MLR [26-29]. In addition, the "steps" between the MLR of stable combustion stage and stable combustion with flame color change stage reduced. The main reason might be that the mass of oxygen per unit volume decreased with the decline of ambient pressure, resulting in the decrease of oxygen concentration between combustible vapor and air on the surface of electrolyte, which caused the oxygen diffusion rate lower in low pressure environment. Thus, the combustion rate was inhibited, while the MLR was reduced and the combustion time was prolonged [26-29].

As shown in Figure 5, the MLR of electrolyte declined with the decrease of pressure, and the main reason was that under a low-pressure environment, MLR might be affected by factors such as mass concentration of oxygen per unit volume and the thermal feedback of 
flames to the unburned surface in order to indicate that the oxygen concentration near the electrolyte surface was basically at a certain value, which was close to 0 . With the decrease of environmental pressure, the oxygen concentration in the air would decline, resulting in the gradient of that between air and the electrolyte surface would reduce, causing a lower diffusion rate of oxygen, then the combustion intensity of gaseous phase weakened, and the MLR decreased. As shown in Figure 5, the MLR of Electrolyte 1 declined with the decrease of pressure. While as for Electrolyte 2, the MLR reduced at first then increased slightly along with the decline of pressure. From the difference of two electrolytes in Hefei $(100.09 \mathrm{kPa})$ and Lhasa $(65.23 \mathrm{kPa})$, when the pressure decreased, the difference between two samples rose, indicating that the pressure had a greater influence on the combustion rate of Electrolyte 2. The MLR of Electrolyte 1 had a roughly exponential relationship with pressure $\left(\dot{m} \propto A P^{\beta}\right)$, which was consistent with previous reports $[21,28,49,50]$, while the MLR of Electrolyte 2 did not exhibit the expected exponential fit. According to previous study [23], for methanol, gasoline, diesel, and $n$-heptane pool fire, the coefficient $\beta$ is $0.7,0.9,1$, and 1.3, respectively. From the above data it could be seen that the coefficient decreased with the decline of carbon weight percentage content in the fuel, which indicates that the lower carbon content in the fuel would decrease the generation of carbon smoke particles, and relatively speaking, the degree of combustion would be more adequate, then the difference of MLR in locations with different pressure would be less, presenting as the lower $\beta$ coefficient.

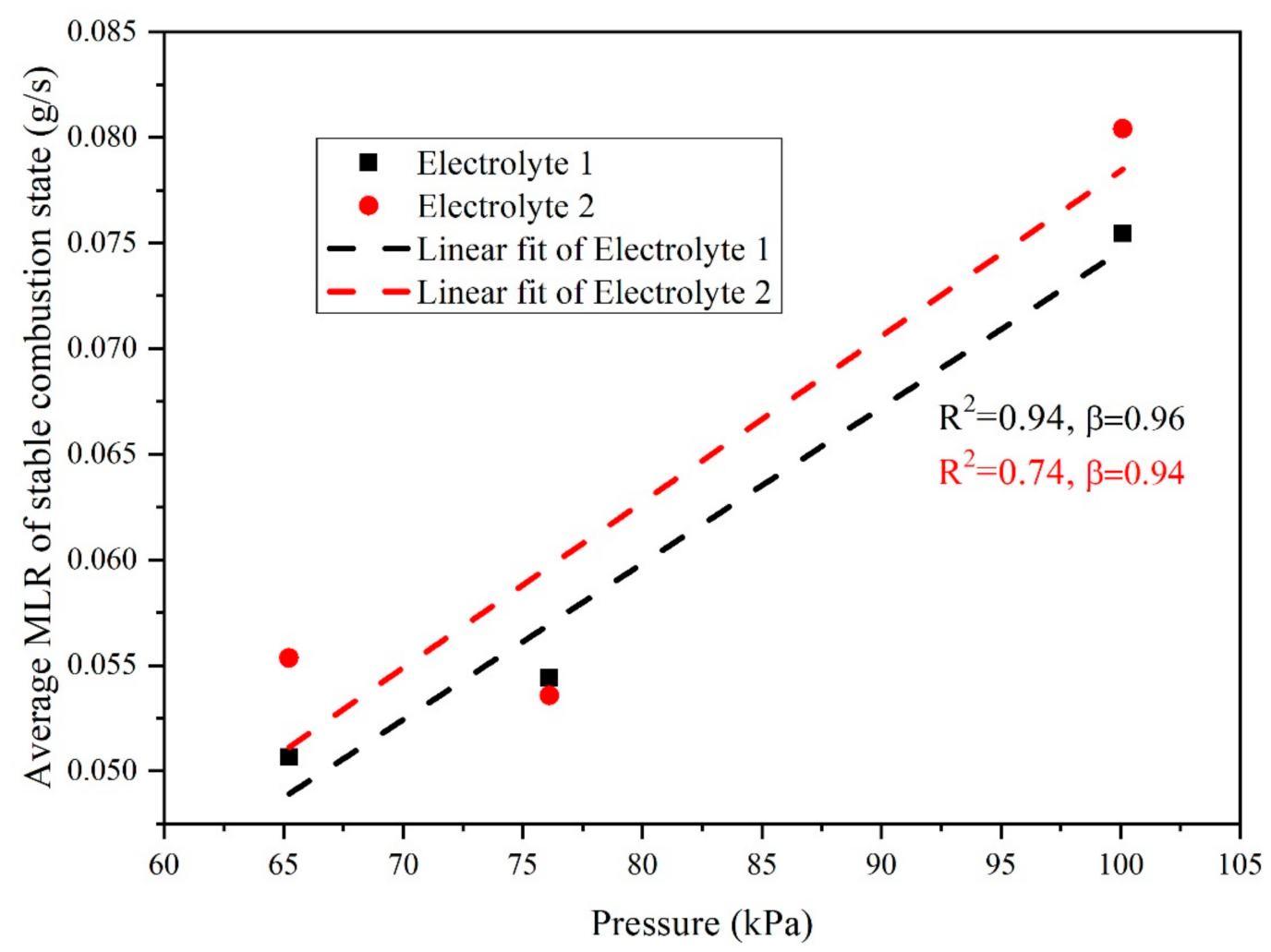

Figure 5. Average MLR and pressure fitting diagram.

\subsection{Flame Centerline Temperature}

Based on the analysis of the mass loss curve, the corresponding average temperature during stable combustion stage and stable combustion with flame color change stage was obtained. Figure 6 shows the temperature curves of the flame centerline just above the liquid level of the two electrolytes in Hefei, Lijiang and Lhasa. As shown in Figure 6a, the temperature change curve of electrolyte flame corresponds well to the divided four stages of electrolyte combustion process in Sections 3.1 and 3.2. The abscissa ( $X$-axis) and ordinate $(Y$-axis) of Figures 7 and 8 are in logarithmic form, but they have completely different 
physical meanings. In Figure 7, the $X$-axis is the relative height from each thermocouple to the liquid fuel level, and the unit is $m$, while the $Y$-axis is the average temperature value detected by each thermocouple during stable combustion stage and stable combustion with flame color change stage. The $X$-axis $z / z^{*}$ in Figure 8 is calculated by the relative height from each thermocouple to the liquid fuel level dividing the characteristic size $z^{*}$ of the fire source, which is a dimensionless ratio, while the $Y$-axis is the relative average temperature rise value from each thermocouple to the environmental temperature. Using $z / z^{*}$ is a common method to describe the temperature distribution of the flame centerline in fire science field [43-46]. Table 4 shows the data of stable combustion stage and stable combustion with flame color change stage of the two electrolytes in Hefei, Lijiang and Lhasa. Table 5 listed the average HRR during the whole stable combustion stage as $Q$ values in Lijiang and Lhasa. As for the decrease of HRR and MLR, there was an increase of the temperature at the very surface of the electrolyte when the pressure decreased, suggesting that the radiative losses in the flame decreased when the pressure dropped, and that the flame stress exerted on the electrolyte decreased as well. Furthermore, it was consistent with the heat flux measurements, which were lower at Lhasa $(65.23 \mathrm{kPa})$ than at Hefei (100.09 kPa).

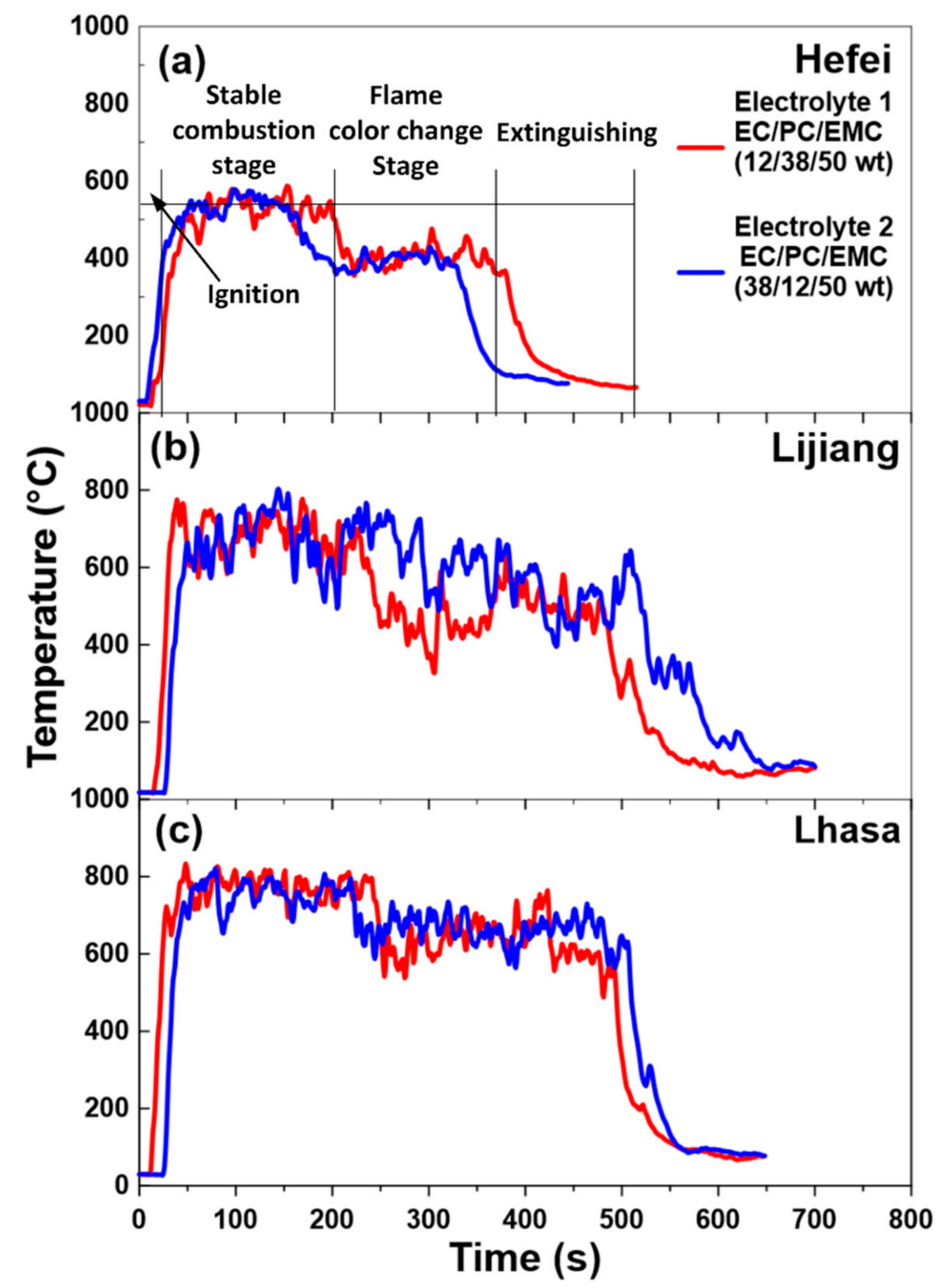

Figure 6. The temperature curves of flame centerline (T1) of two electrolytes in (a) Hefei (100.09 kPa), (b) Lijiang (76.11 kPa) and (c) Lhasa (65.23 kPa). 


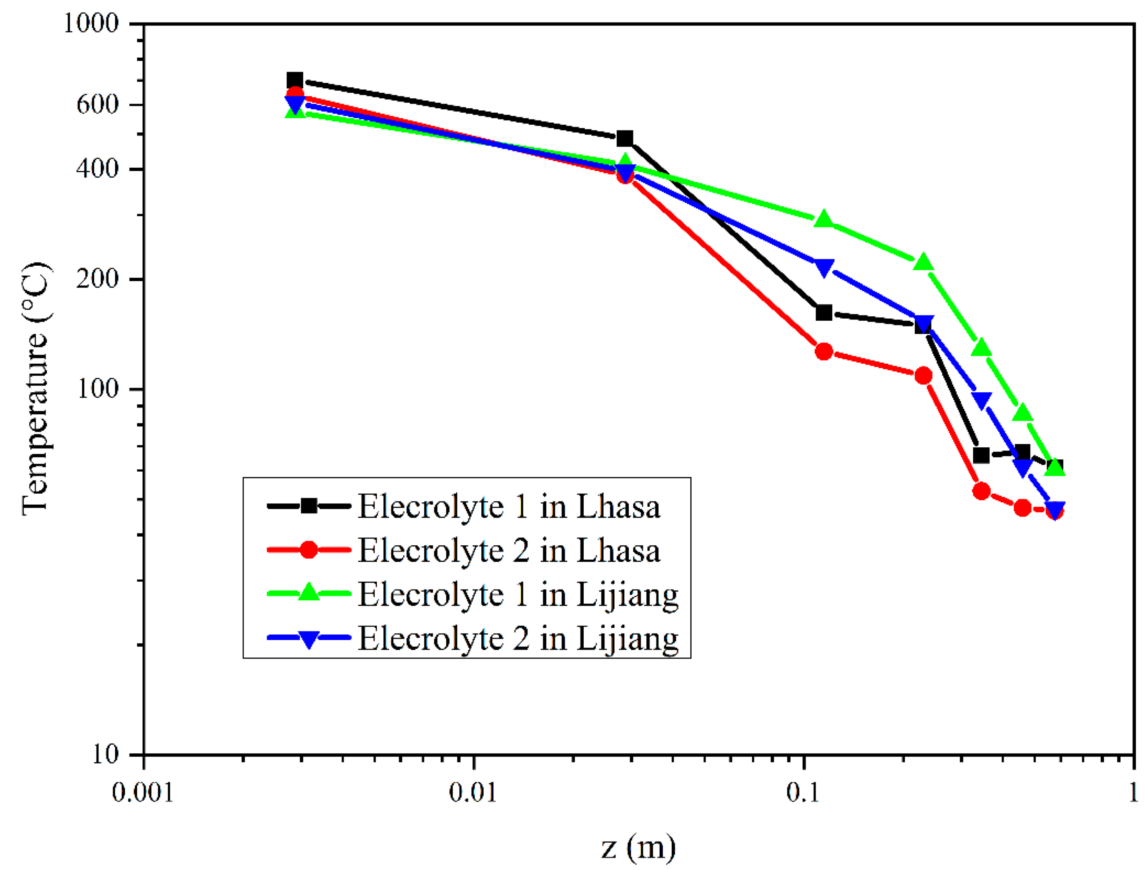

Figure 7. The average fire centerline temperatures at different thermocouple positions (height above the sample liquid level) of the two samples under different pressures during the stable combustion stage.

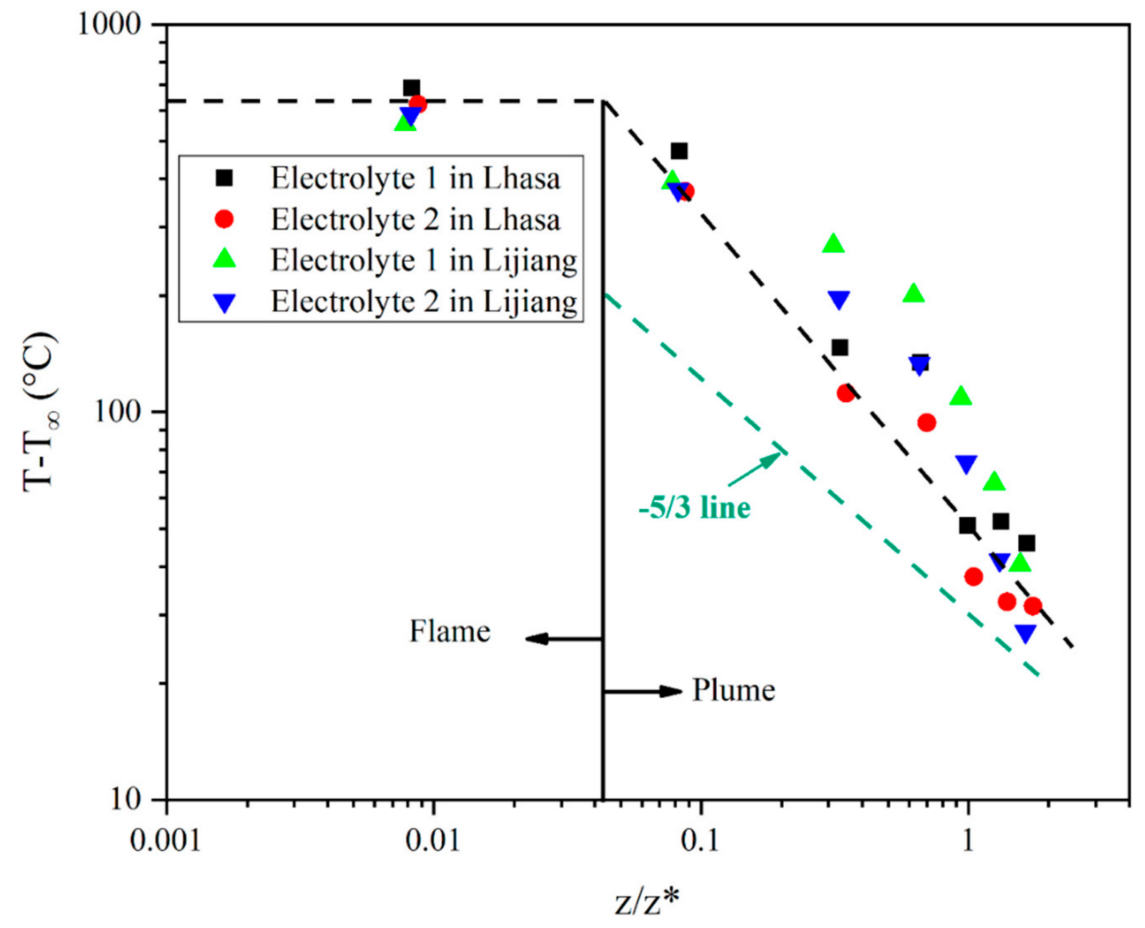

Figure 8. The average fire centerline temperatures rising distribution in different flame plume zones. 
Table 4. The list of average flame centerline temperature for two electrolytes at stable combustion stage and stable combustion with flame color change stage in Hefei (100.09 kPa), Lijiang (76.11 kPa) and Lhasa (65.23 kPa).

\begin{tabular}{|c|c|c|c|c|}
\hline \multirow{3}{*}{ Experimental Region } & \multicolumn{4}{|c|}{ Average Temperature $\left({ }^{\circ} \mathrm{C}\right)$} \\
\hline & \multicolumn{2}{|c|}{$\begin{array}{c}\text { Electrolyte } 1 \\
\text { EC/PC/EMC }(12 / 38 / 50 \mathrm{wt})\end{array}$} & \multicolumn{2}{|c|}{$\begin{array}{c}\text { Electrolyte } 2 \\
\text { EC/PC/EMC }(38 / 12 / 50 \mathrm{wt})\end{array}$} \\
\hline & $\begin{array}{c}\text { Stable Combustion } \\
\text { Stage }\end{array}$ & $\begin{array}{c}\text { Stable Combustion } \\
\text { with Flame Color } \\
\text { Change Stage }\end{array}$ & $\begin{array}{c}\text { Stable Combustion } \\
\text { Stage }\end{array}$ & $\begin{array}{c}\text { Stable Combustion } \\
\text { with Flame Color } \\
\text { Change Stage }\end{array}$ \\
\hline Hefei (100.09 kPa) & 524 & 405 & 527 & 395 \\
\hline Lijiang (76.11 kPa) & 679 & 480 & 676 & 548 \\
\hline Lhasa $(65.23 \mathrm{kPa})$ & 786 & 693 & 730 & 555 \\
\hline
\end{tabular}

Table 5. The list of average HRR in Lijiang $(76.11 \mathrm{kPa})$ and Lhasa $(65.23 \mathrm{kPa})$ as $Q$ values during the $z^{*}$ calculation.

\begin{tabular}{ccc}
\hline$Q$ & Lijiang (76.11 kPa) & Lhasa (65.23 kPa) \\
\hline Electrolyte 1 & 98 & 83 \\
Electrolyte 2 & 87 & 72 \\
\hline
\end{tabular}

From Figure 7, the decrease trend of temperature values obtained by thermocouples and the 7018 temperature measuring module in Lijiang was more obvious than that in Lhasa with the thermocouple position range from $0.04 \mathrm{~m}$ to $0.20 \mathrm{~m}$ height from the liquid level, which was due to the higher flame height in Lhasa. In the combustion process, the electrolyte would be gasified, and the combustible gas would rise with the effect of heat flow, entraining air to complete combustion. At low pressure, the air density is lower, and the oxygen concentration is reduced, so more air entrainment was needed to bring enough oxygen to complete the combustion process; this increased the entrainment time and made the flame height increase $[51,57]$. Therefore, between 0.04 and $0.20 \mathrm{~m}$ height above the pool surface, there was a faster decline rate of fire temperature in Lijiang.

In order to further analyze the flame temperature of electrolyte, a characteristic length $z^{*}$ was induced to describe the fire size, which was defined as Equation (2) $[21,28,51-54]$ :

$$
z^{*}=\left(\frac{Q}{\rho_{\infty} c_{p} T_{\infty} \sqrt{g}}\right)^{\frac{2}{5}}
$$

where $Q$ is the HRR, $\rho_{\infty}, c_{p}, T_{\infty}$ and $g$ are the density, specific heat capacity of air, ambient temperature, and gravity acceleration, respectively.

According to the experimental results, flame plume temperatures and characteristic length $z^{*}$ which considering the influence of pressure were fitted to evaluate that whether the flame flume temperature of electrolyte pool fire was corresponding with the threezone distribution proposed by Mc Caffrey model, as shown in Figure 8. Different from hydride, as for the electrolyte pool fire, the slope of intermittent region should be between that of flame region and plume region according to Mc Caffrey's fire plume temperature distribution model, presenting a ternary form temperature distribution. Nevertheless, as for electrolyte, the boundary between intermittent region and plume region was not clear, and it was hard to distinguish the two regions exactly. Thus, the flame plume of the electrolyte pool fire could be divided into two areas-flame zone and plume zone-which was consistent with a previous study [36]. As indicated in the figure, the temperature in flame zone remained around $750{ }^{\circ} \mathrm{C}$.

From Table 4, the flame temperature of stable combustion stage was higher than that of stable combustion with flame color change stage. The explanation for this fire behavior is that the linear carbonate EMC was the main fuel of stable combustion stage because of its lowest flash point and strongest volatility in the organic solvent mixture system. The 
residual organic solvents $\mathrm{PC}$ and EC in the solution had low volatility and combustion heat due to their ring structure. The stable ring structure led to the decrease of the free radical formation rate and the combustion rate of electrolyte pool fire, which resulted in the decrease of flame temperature.

The lower oxygen diffusion rate in a low pressure environment will lead to the decrease of combustion rate per unit volume and the extension of fuel burning time, which could explain that the burning duration of electrolyte in Lijiang and Lhasa was about 70\% and $50 \%$ longer than that in Hefei, respectively.

\subsection{Radiation Heat Flux}

Flames can be regarded as mixtures of high temperature gas, soot particles and other combustion products, so flame radiation consists of soot radiation and gas radiation. Environmental pressure will not only have a significant impact on soot particles, but also affect the flame radiation heat flux, thus affecting the combustion rate of the flame, resulting in changes in flame color and height.

Figure 9 illustrates the radiation heat flux of two electrolytes burning in Hefei, Lijiang and Lhasa. As shown in Figure 9, the change trend of electrolyte in Hefei and Lijiang was similar, which could be corresponding with the previously divided four combustion stages. However, the radiation heat flux generated by electrolyte combustion in Hefei rose and fell faster than that in Lijiang and Lhasa, while which can well verify that the flame radiation heat flux loss was significantly reduced at low pressure. It is worth noting that the radiation heat flux measured in Lhasa was far less than that measured in Hefei and Lijiang, which can be attributed to the decrease of the volume fraction of soot particles under low pressure [22-24]. From the radiation heat flux curves as shown in Figure 9, they were proportionable with the corresponding HRR curves in Section 3.5, which indicates that during the combustion process the heat radiative flux was positively associated with HRR.

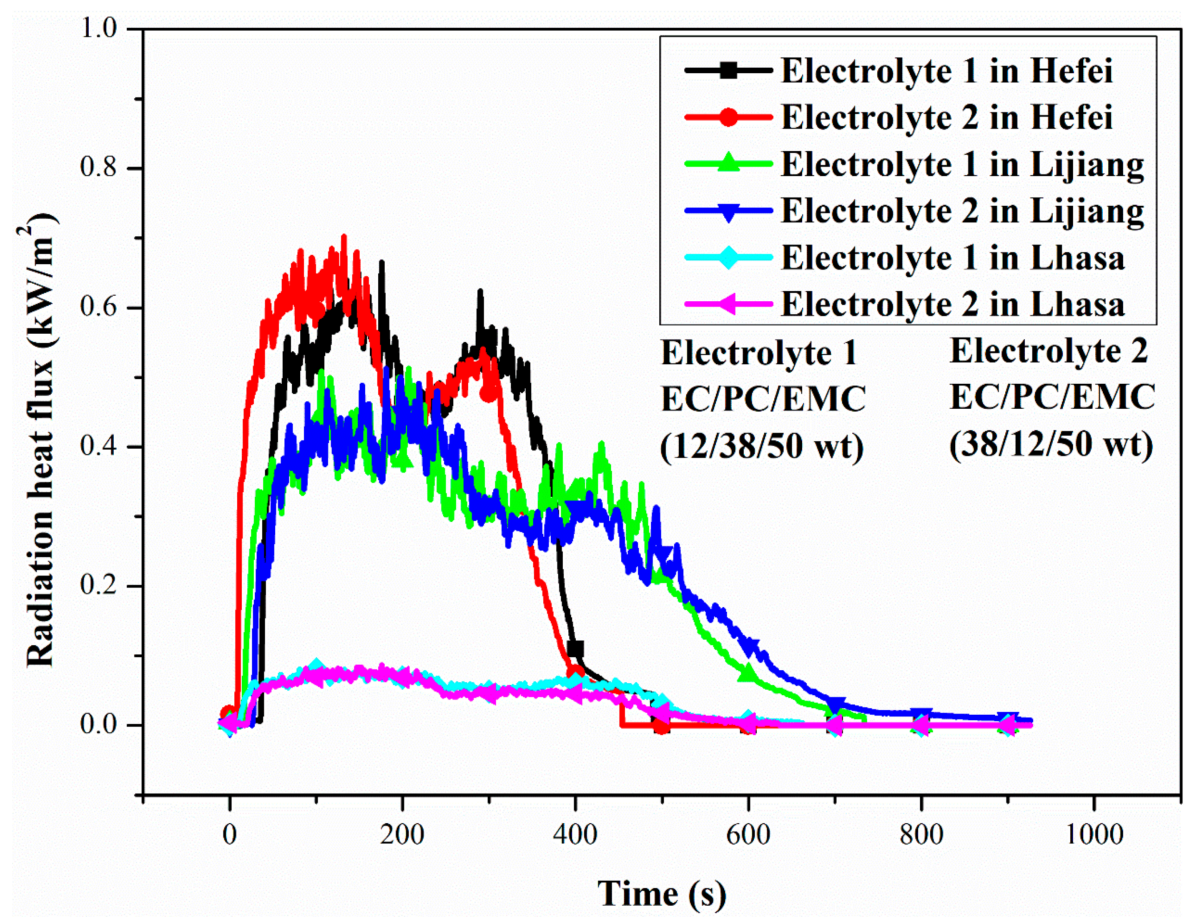

Figure 9. Radiation heat flux of two electrolytes burning in Hefei (100.09 kPa), Lijiang (76.11 kPa) and Lhasa $(65.23 \mathrm{kPa})$.

\subsection{Heat Release Rate}

HRR is an important parameter to evaluate the fire risk of battery packs $[15,25]$. A lot of heat will be released from the electrolyte during the combustion process. Considering 
the actual working conditions of LIBs, the heat released from the electrolyte may cause TR of adjacent batteries during the processing. Therefore, it is necessary to evaluate the HRR of electrolytes.

In this paper, a cone calorimeter was applied to measure HRR in Hefei and Lhasa (since the limitation of experimental condition, there was no such equipment in Lijiang), and the ambient pressure will have a significant impact on the calculation of the volume flow in the exhaust pipe. According to the research of Niu et al. [26], the volume flow ratio of the gas in the exhaust pipe in Hefei and Lhasa is equal to the molar volume ratio of the two places, that is, 22.4:17.8. Environmental pressure would influence the gas MFR calculation in the exhaust duct of cone calorimeter. According to International Standardization Organization (ISO) 9705 standard [58], the calculation of HRR is as follows:

$$
\begin{gathered}
\dot{V}_{298}=22.4 \sqrt{P_{a} / P_{0}}\left(A K_{t} / K_{p}\right)\left(\Delta P / T_{s}\right)^{1 / 2} \\
\dot{q}=H R R=E \dot{V}_{298} \chi_{\mathrm{O}_{2}}^{a}\left(\frac{\phi}{\phi(\alpha-1)+1}\right)-\frac{E}{E_{\mathrm{C}_{3} H_{8}}} \dot{q}_{b}
\end{gathered}
$$

where, $\dot{V}_{298}$ is the volume flow rate of gas in the exhaust duct under the standard atmospheric pressure and the temperature of $25^{\circ} \mathrm{C}$, whose unit is $\mathrm{m}^{3} / \mathrm{s}$.

$P_{a}$ is the environmental pressure.

$P_{0}$ is the barometric pressure when the altitude is $0 \mathrm{~m}$.

$T_{S}$ is the gas temperature in the exhaust duct, and the unit is $\mathrm{K}$.

$\Delta P$ is the pressure drop measured by orifice plate flowmeter, whose unit is Pa.

$A$ is the cross-sectional area (CSA) of exhaust duct, $\mathrm{m}^{2}$.

$\mathrm{K} t$ is the ratio of the average mass flow per unit area to mass flow per unit area in the center of the exhaust duct.

$K p$ is the Reynolds number correction for the bi-directional probe suggested by Mc Caffrey and Heskestad.

$E_{\mathrm{C}_{3} \mathrm{H}_{8}}$ is a constant as $16.8 \times 10^{3} \mathrm{~kJ} / \mathrm{m}^{3}$.

$\alpha$ is a constant as 1.105 .

$\chi_{\mathrm{O}_{2}}^{a}$ is the ambient mole fraction of oxygen including water vapor.

$\dot{q}_{b}$ is the HRR from the burner.

Therefore, in Lhasa $(65.23 \mathrm{kPa}), \dot{V}_{298}$ is calculated as below:

$$
\dot{V}_{298}=17.8\left(A K_{t} / K_{p}\right)\left(\Delta P / T_{s}\right)^{1 / 2}
$$

Based on this relationship, the HRR of the two electrolyte samples in Lhasa was modified. The experimental results of Hefei and Lhasa are shown in Figures 10 and 11, respectively.

It can be seen from Figure 10 that the change trend and peak value of HRR curves of the two electrolytes were basically consistent. In addition, the HRR curves of the two electrolytes confirmed the above division of electrolyte combustion stage. Due to the influence of linear carbonate and cyclic carbonate, there were two relatively stable stages (stable combustion stage and stable combustion with flame color change stage) in the combustion process of electrolyte. During stable combustion stage, linear carbonate was the main fuel to maintain electrolyte pool fire. With the continuous accumulation of heat, the combustion rate increased rapidly and the HRR reached to the peak value. With the exhaustion of EMC, EC and PC with similar volatility became the main fuels, and the evaporation rate of these two organic solvents was lower than that of EMC, resulting in the decrease of HRR. 


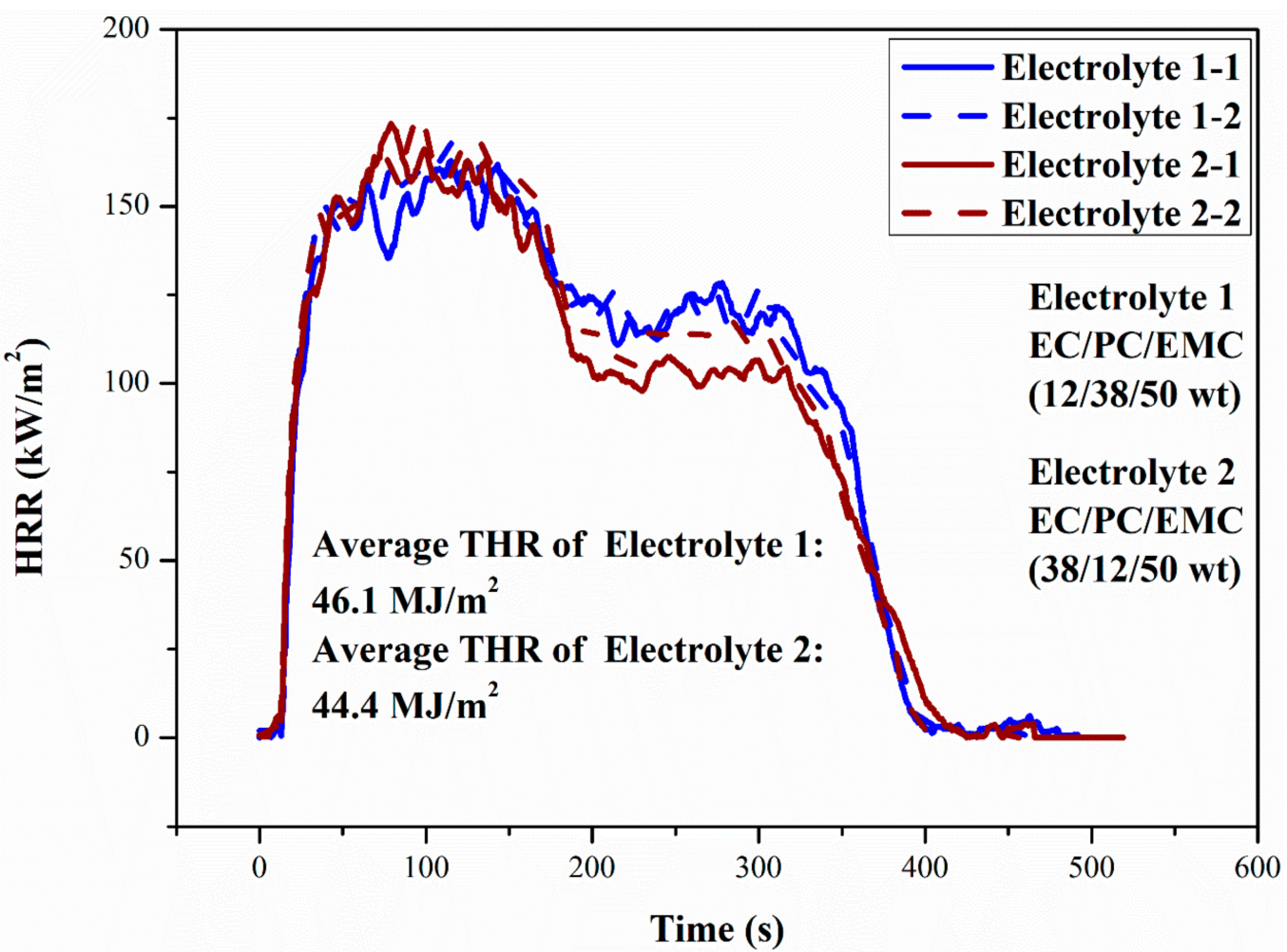

Figure 10. HRR curves of two electrolytes in Hefei $(100.09 \mathrm{kPa})$. The results for duplicate samples are given as a dashed line in the figure.

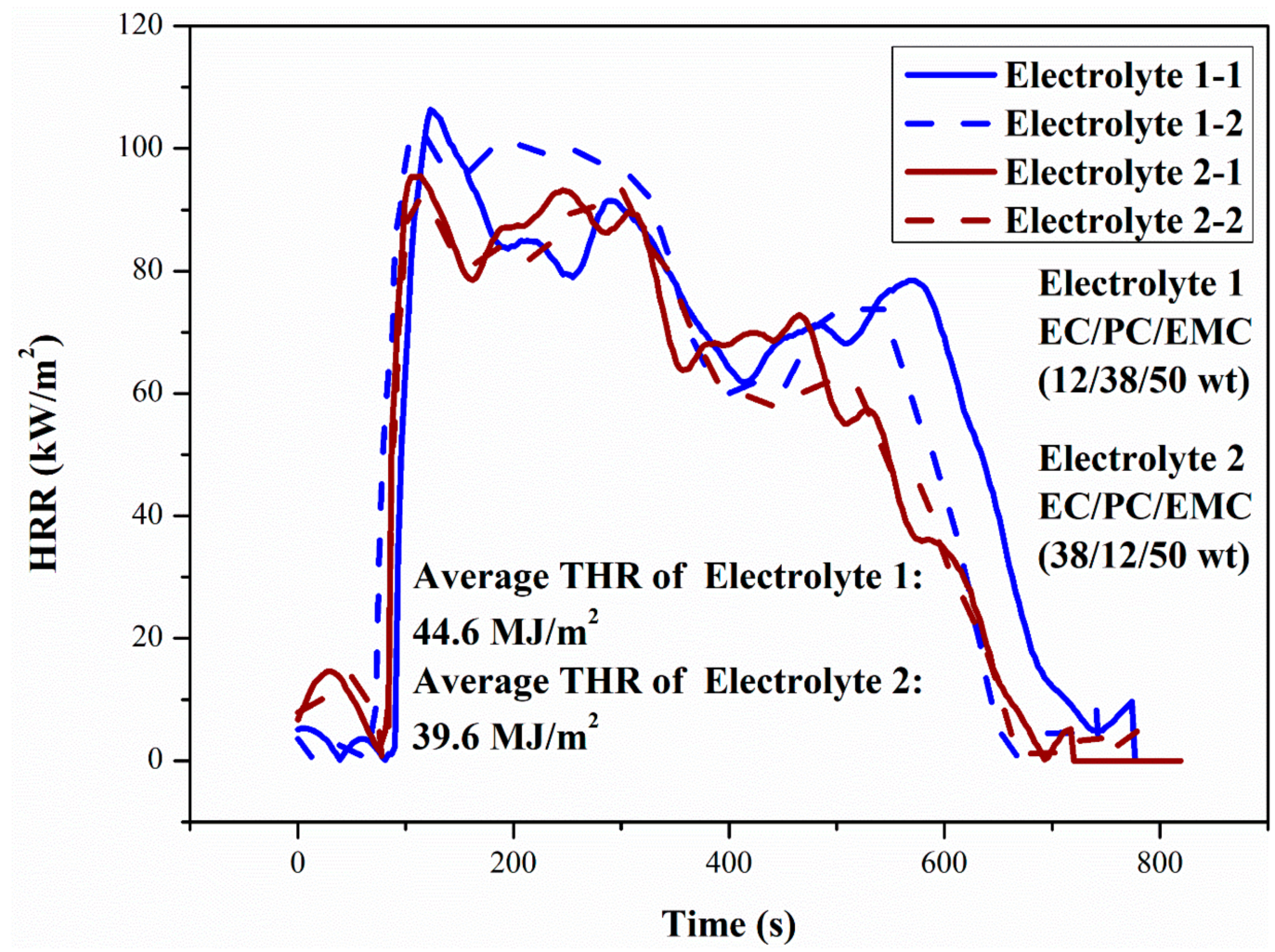

Figure 11. HRR curves of two electrolytes in Lhasa $(65.23 \mathrm{kPa})$. The results for duplicate samples are given as a dashed line in the figure.

Comparing Figures 10 and 11, it can be found that the decrease of ambient pressure does not change the trend of the HRR curve of the electrolyte. It can be found that the 
HRR and total heat release (THR) of electrolyte pool fire declined with the decrease of environmental pressure, which was consistent with previous studies on LIBs and liquid fuels [27-36].

The pHRR and THR of Electrolyte 2 were a little lower than those of Electrolyte 1, reflecting a higher thermal safety, and the conductivity of it was increased by $15.8 \%$ compared with that of Electrolyte 1, so Electrolyte 2 has higher comprehensive performance.

Electrolyte is one of the main components in LIBs that releases most of the heat during the TR process. Quantitatively evaluating the fire risk of electrolyte could help develop safer LIBs [55]. From this study, on the premise of maintaining good electrochemical performance, several potential useful pieces of advice for decreasing the thermal hazard of LIBs are proposed: (1) OC calorimetry based on cone calorimeter is a suitable method to measure the HRR of electrolyte. The lower the HRR, the lower the fire hazard. (2) The environmental pressure would influence the key parameters such as burning duration, peak value of HRR and MLR. The THR under low-pressure conditions was lower than that under atmospheric pressure, so the impact of pressure should be taken into consideration during the transportation and storage of LIBs. (3) Fire retardant could be potentially added to electrolytes to probably increase the safety of LIBs. (4) Besides enhancing materials properties, a battery thermal management system (BTMS) with fire extinguishant is another method to reduce thermal risk from the external aspect.

\section{Conclusions}

In this paper, the combustion characteristics of $1 \mathrm{~mol} / \mathrm{L} \mathrm{LiBF}_{4}$ involved in $\mathrm{EC} / \mathrm{PC} / \mathrm{EMC}$ $(12 / 38 / 50$ or $38 / 12 / 50$ mass ratio) electrolyte were analyzed, and the influence of lowvoltage environment on the fire risk of LIB electrolyte was studied:

(1) The combustion process of $\mathrm{LiBF}_{4}$ in $\mathrm{EC} / \mathrm{PC} / \mathrm{EMC}$ electrolyte system with different mass ratio without external radiation could be divided into four stages: ignition, stable combustion stage, stable combustion with flame color change stage and extinguishing;

(2) The flame centerline temperature increased with the decrease of ambient pressure, which was mainly due to the significant decline of flame radiation heat loss at low pressure;

(3) The mass of oxygen per unit volume reduced with the decrease of pressure, resulting in a decline of the oxygen concentration between combustible vapor and air on the surface of electrolyte, resulting in lower oxygen diffusion rate under low pressure conditions, thus inhibiting the combustion rate of the electrolyte and the MLR fall, reducing the steps between MLR in the stable combustion stage and the stable combustion with flame color change stage, and prolonging the burning duration.

(4) The pHRR and THR of the two electrolytes were almost the same, but those of Electrolyte 2 were slightly lower, and its conductivity was increased by $15.8 \%$ compared with Electrolyte 1. Thus, Electrolyte 2 has a relatively lower fire hazard and better comprehensive performance.

Author Contributions: Conceptualization, Q.H.; Data curation, K.Z. (Kaihui Zheng); Formal analysis, K.Z. (Kaihui Zheng); Funding acquisition, C.L.; Investigation, C.L.; Methodology, Q.H.; Project administration, Y.Z.; Resources, Q.H.; Software, K.Z. (Kaihui Zheng); Supervision, Y.Z.; Validation, K.Z. (Kaihui Zheng); Visualization, K.Z. (Kai Zhu); Writing-original draft, K.Z. (Kaihui Zheng); Writing-review \& editing, Q.H. All authors have read and agreed to the published version of the manuscript.

Funding: National Natural Science Foundation of China (No: 51906238); Open Project Program of the State Key Laboratory of Fire Science (No. HZ2020-KF04); Science Foundation of North University of China (No. XJJ201912); Scientific and Technologial Innovation Programs (STIP) of Higher Education Institutions in Shanxi (No. 2019L050).

Institutional Review Board Statement: Not applicable.

Informed Consent Statement: Not applicable. 
Data Availability Statement: The data presented in this study are available on request from the corresponding author.

Acknowledgments: This study has been sponsored by National Natural Science Foundation of China (No: 51906238) and the Open Project Program of the State Key Laboratory of Fire Science (No. HZ2020-KF04). The project was supported by Science Foundation of North University of China (No. XJJ201912). Also, this work was supported by Scientific and Technologial Innovation Programs (STIP) of Higher Education Institutions in Shanxi (No. 2019L050). The authors gratefully acknowledge these supports.

Conflicts of Interest: There are no conflicts of interest to declare.

\section{References}

1. Hou, P.; Wang, X.; Wang, D.; Song, D.; Shi, X.; Zhang, L.; Guo, J.; Zhang, J. A novel core-concentration gradient-shelled $\mathrm{LiNi}_{0.5} \mathrm{Co}_{0.2} \mathrm{Mn}_{0.3} \mathrm{O}_{2}$ as high-performance cathode for lithium-ion batteries. RSC Adv. 2014, 4, 15923-15929. [CrossRef]

2. Eshetu, G.G.; Grugeon, S.; Gachot, G.; Mathiron, D.; Armand, M.; Laruelle, S. LiFSI vs. LiPF6 electrolytes in contact with lithiated graphite: Comparing thermal stabilities and identification of specific SEI-reinforcing additives. Electrochim. Acta 2013, 102, 133-141. [CrossRef]

3. Madec, L.; Ma, L.; Nelson, K.J.; Petibon, R.; Sun, J.; Hill, I.G.; Dahn, J.R. The Effects of a Ternary Electrolyte Additive System on the Electrode/Electrolyte Interfaces in High Voltage Li-Ion Cells. J. Electrochem. Soc. 2016, 163, A1001-A1009. [CrossRef]

4. Lagadec, M.F.; Zahn, R.; Wood, V. Characterization and performance evaluation of lithium-ion battery separators. Nat. Energy 2019, 4, 16-25. [CrossRef]

5. Nelson, K.J.; Xia, J.; Dahn, J.R. Studies of the Effect of Varying Prop-1-ene-1,3-sultone Content in Lithium Ion Pouch Cells. J. Electrochem. Soc. 2014, 161, A1884-A1889. [CrossRef]

6. Zhang, B.; Liu, H. Theoretical prediction model and experimental investigation of detonation limits in combustible gaseous mixtures. Fuel 2019, 258, 116132. [CrossRef]

7. Lee, C.W. A Novel Flame-Retardant Additive for Lithium Batteries. Electrochem. Solid-State Lett. 1999, 3, 63-65. [CrossRef]

8. Kizilel, R.; Sabbah, R.; Selman, J.R.; Al-Hallaj, S. An alternative cooling system to enhance the safety of Li-ion battery packs. J. Power Sources 2009, 194, 1105-1112. [CrossRef]

9. Zaghib, K.; Dubé, J.; Dallaire, A.; Galoustov, K.; Guerfi, A.; Ramanathan, M.; Benmayza, A.; Prakash, J.; Mauger, A.; Julien, C.M. Enhanced thermal safety and high power performance of carbon-coated $\mathrm{LiFePO}_{4}$ olivine cathode for Li-ion batteries. J. Power Sources 2012, 219, 36-44. [CrossRef]

10. Seo, J.; Sankarasubramanian, S.; Kim, C.; Hovington, P.; Prakash, J.; Zaghib, K. Thermal characterization of Li/sulfur, Li/S$\mathrm{LiFePO}_{4}$ and $\mathrm{Li} / \mathrm{S}-\mathrm{LiV}_{3} \mathrm{O}_{8}$ cells using Isothermal Micro-Calorimetry and Accelerating Rate Calorimetry. J. Power Sources 2015, 289, 1-7. [CrossRef]

11. Chen, H.; Chen, J.; Zhang, W.; Xie, Q.; Che, Y.; Wang, H.; Xing, L.; Xu, K.; Li, W. Enhanced cycling stability of high-voltage lithium metal batteries with a trifunctional electrolyte additive. J. Mater. Chem. A 2020, 8, 22054-22064. [CrossRef]

12. Li, M.; Wang, C.; Chen, Z.; Xu, K.; Lu, J. New Concepts in Electrolytes. Chem. Rev. 2020, 120, 6783-6819. [CrossRef] [PubMed]

13. Borodin, O.; Self, J.; Persson, K.A.; Wang, C.; Xu, K. Uncharted Waters: Super-Concentrated Electrolytes. Joule 2020, 4, 69-100. [CrossRef]

14. Jiang, L.; Liu, L.; Yue, J.; Zhang, Q.; Zhou, A.; Borodin, O.; Suo, L.; Li, H.; Chen, L.; Xu, K.; et al. High-Voltage Aqueous Na-Ion Battery Enabled by Inert-Cation-Assisted Water-in-Salt Electrolyte. Adv. Mater. 2019, 32, e1904427. [CrossRef] [PubMed]

15. Eshetu, G.G.; Grugeon, S.; Laruelle, S.; Boyanov, S.; Lecocq, A.; Bertrand, J.; Marlair, G. In-depth safety-focused analysis of solvents used in electrolytes for large scale lithium ion batteries. Phys. Chem. Chem. Phys. PCCP 2013, 15, 9145-9155. [CrossRef]

16. Fu, Y.; Lu, S.; Shi, L.; Cheng, X.; Zhang, H. Combustion Characteristics of Electrolyte Pool Fires for Lithium Ion Batteries. J. Electrochem. Soc. 2016, 163, A2022-A2028. [CrossRef]

17. Ribière, P.; Grugeon, S.; Morcrette, M.; Boyanov, S.; Laruelle, S.; Marlair, G. Investigation on the fire-induced hazards of Li-ion battery cells by fire calorimetry. Energy Environ. Sci. 2012, 5, 5271-5280. [CrossRef]

18. Gachot, G.; Grugeon, S.; Eshetu, G.G.; Mathiron, D.; Ribière, P.; Armand, M.; Laruelle, S. Thermal behaviour of the lithiatedgraphite/electrolyte interface through GC/MS analysis. Electrochim. Acta 2012, 83, 402-409. [CrossRef]

19. Armand, M.; Tarascon, J.M. Building better batteries. Nature 2008, 451, 652-657. [CrossRef]

20. Li, Z.; He, Y.; Zhang, H.; Wang, J. Combustion characteristics of n-heptane and wood crib fires at different altitudes. Proc Combust. Inst. 2009, 32, 2481-2488. [CrossRef]

21. Fu, Y. Studies on Combustion Characteristics of Typical Lithium lon Battery and Its Electrolyte as Well as Influence Mechanism of Air Transport Environment on Them; University of Science and Technology of China: Hefei, China, 2017. (In Chinese)

22. Shinotake, A.; Koda, S.; Akita, K. An Experimental Study of Radiative Properties of Pool Fires of an Intermediate Scale. Combust. Sci. Technol. 2010, 43, 85-97. [CrossRef]

23. Wieser, D.; Jauch, P.; Willi, U. The influence of high altitude on fire detector test fires. Fire Saf. J. 1997, 29, 195-204. [CrossRef]

24. Bento, D.; Thomson, K.; Gulder, O. Soot formation and temperature field structure in laminar propane-air diffusion flames at elevated pressures. Combust. Flame 2006, 145, 765-778. [CrossRef] 
25. Zhang, W.; Chen, X.; Chen, Q.; Ding, C.; Liu, J.; Chen, M.; Wang, J. Combustion calorimetry of carbonate electrolytes used in lithium ion batteries. J. Fire Sci. 2014, 33, 22-36. [CrossRef]

26. Niu, Y.; He, Y.; Hu, X.; Zhou, D.; Lin, C.; Yin, J.; Yao, W.; Wang, J. Experimental study of burning rates of cardboard box fires near sea level and at high altitude. Proc. Combust. Inst. 2013, 34, 2565-2573. [CrossRef]

27. Chen, M.; Liu, J.; Lin, X.; Huang, Q.; Yuen, R.; Wang, J. Combustion characteristics of primary lithium battery at two altitudes. J. Therm. Anal. Calorim. 2016, 124, 865-870. [CrossRef]

28. Liu, C.; Huang, Q.; Zheng, K.; Qin, J.; Zhou, D.; Wang, J. Impact of Lithium Salts on the Combustion Characteristics of Electrolyte under Diverse Pressures. Energies 2020, 13, 5373. [CrossRef]

29. Chen, X.; Lu, S.; Li, C.; Zhang, J.; Liew, K.M. Experimental study on ignition and combustion characteristics of typical oils. Fire Mater. 2014, 38, 409-417. [CrossRef]

30. Mulholland, G.; Henzel, V.; Babrauskas, V. The Effect Of Scale On Smoke Emission. Fire Saf. Sci. 1989, 2, 347-357. [CrossRef]

31. Huang, Q.; Liu, C.; Wei, R.; Wang, J. Experimental study of polyethylene pyrolysis and combustion over HZSM-5, HUSY, and MCM-41. J. Hazard. Mater. 2017, 333, 10-22. [CrossRef] [PubMed]

32. Qin, J.; Liu, C.; Huang, Q. Simulation on fire emergency evacuation in special subway station based on Pathfinder. Case Stud. Therm. Eng. 2020, 21, 100677. [CrossRef]

33. Huang, Q.; Ma, L.; Liu, A.; Ma, X.; Li, J.; Wang, J.; Dahn, J.R. The reactivity of charged positive $\mathrm{Li}_{1-\mathrm{n}}\left[\mathrm{Ni}_{\mathrm{x}} \mathrm{Mn}_{\mathrm{y}} \mathrm{Co}_{\mathrm{z}}\right] \mathrm{O}_{2}$ electrodes with electrolyte at elevated temperatures using accelerating rate calorimetry. J. Power Sources 2018, 390, 78-86. [CrossRef]

34. Cao, W.; Liu, Y.; Chen, R.; Li, W.; Zhang, Y.; Xu, S.; Cao, X.; Huang, Q.; Tan, Y. Pressure release characteristics of premixed hydrogen-air mixtures in an explosion venting device with a duct. Int. J. Hydrogen Energy 2021, 46, 8810-8819. [CrossRef]

35. Huang, Q.; Glazier, S.; Louli, A.; McArthur, M.; Liu, C.; Schrooten, J.; Dahn, J.R. Effects of graphite heat-treatment temperature on single-crystal $\mathrm{Li}\left[\mathrm{Ni}_{5} \mathrm{Mn}_{3} \mathrm{Co}_{2}\right] \mathrm{O}_{2}$ /graphite pouch cells. J. Electrochem. Soc. 2020, 167, 080543. [CrossRef]

36. Liu, C.; Xu, D.; Weng, J.; Zhou, S.; Li, W.; Wan, Y.; Jiang, S.; Zhou, D.; Wang, J.; Huang, Q. Phase change materials application in battery thermal management system: A review. Materials 2020, 13, 4622. [CrossRef]

37. $\mathrm{Xu}, \mathrm{K}$. Nonaqueous liquid electrolytes for lithium-based rechargeable batteries. Chem. Rev. 2004, 104, 4303-4417. [CrossRef] [PubMed]

38. Wang, B.; Qu, Q.; Xia, Q.; Wu, Y.; Zhou, D.; Gu, X.; Ree, T. 2-Phenylimidazole as an additive to prevent the co-intercalation of propylene carbonate in organic electrolyte for lithium ion batteries. J. Power Sources 2009, 189, 757-760. [CrossRef]

39. Smart, M.C.; Ratnakumar, B.V.; Behar, A.; Whitcanack, L.D.; Yu, J.S.; Alamgir, M. Gel polymer electrolyte lithium-ion cels with improved low temperature performance. J. Power Sources 2007, 165, 535-543. [CrossRef]

40. Wang, B.; Zhang, H.; Yang, L.; Qu, Q.; Wu, Y.; Gan, C.; Zhou, D. Improving electrochemical performance of graphite carbon in PC-based electrolytes by using N-vinyl-2-pyrrolidone as an additie. Electrochem. Commun. 2008, 10, 1571-1574. [CrossRef]

41. Zhang, B.; Chang, X.; Bai, C. End-wall ignition of methane-air mixtures under the effects of CO2/Ar/N2 fluidic jets. Fuel 2020, 270, 117485. [CrossRef]

42. Wang, Q.; Ping, P.; Zhao, X.; Chu, G.; Sun, J.; Chen, C. Thermal runaway caused fire and explosion of lithium ion battery. J. Power Sources 2012, 208, 210-224. [CrossRef]

43. Golubkov, A.W.; Fuchs, D.; Wagner, J.; Wiltsche, H.; Stangl, C.; Fauler, G.; Voitic, G.; Thaler, A.; Hacker, V. Thermal-runaway experiments on consumer Li-ion batteries with metal-oxide and olivin-type cathodes. RSC Adv. 2014, 4, 3633-3642. [CrossRef]

44. Larsson, F.; Bertilsson, S.; Furlani, M.; Albinsson, I.; Mellander, B. Gas explosions and thermal runaways during external heating abuse of commercial lithium-ion graphite- $\mathrm{LiCoO}_{2}$ cells at different levels of ageing. J. Power Sources 2018, 373, 220-231. [CrossRef]

45. Somandepalli, V.; Marr, K.; Horn, Q. Quantification of Combustion Hazards of Thermal Runaway Failures in Lithium-Ion Batteries. SAE Int. J. Altern. Powertrains 2014, 3, 98-104. [CrossRef]

46. Fernandes, Y.; Bry, A.; de Persis, S. Identification and quantification of gases emitted during abuse tests by overcharge of a commercial Li-ion battery. J. Power Sources 2018, 389, 106-119. [CrossRef]

47. Ping, P.; Wang, Q.; Huang, P.; Li, K.; Sun, J.; Kong, D.; Chen, C. Study of the fire behavior of high-energy lithium-ion batteries with full-scale burning test. J. Power Sources 2015, 285, 80-89. [CrossRef]

48. Huang, P.; Wang, Q.; Li, K.; Ping, P.; Sun, J. The combustion behavior of large scale lithium titanate battery. Sci. Rep. 2015, 5, 7788. [CrossRef]

49. De Ris, J.L.; Wu, P.K.; Heskestad, G. Radiation fire modeling. Proc. Combust. Inst. 2000, 28, 2751-2759. [CrossRef]

50. Tu, R.; Lei, J.; Wang, Y.; Fang, J.; Zhang, Y. Small Scale Pool Fire Burning Rate Under Reduced Atmospheric Pressure Using Pressure Modeling. J. Combust. Sci. Technol. 2010, 5, 16. [CrossRef]

51. Zhou, Z.; Wei, Y.; Li, H.; Yuen, R.; Jian, W. Experimental analysis of low air pressure influences on fire plumes. Int. J. Heat Mass Transf. 2014, 70, 578-585. [CrossRef]

52. Quintiere, J.; Grove, B. A unified analysis for fire plumes. Symp. Int. Combust. 1998, 27, 2757-2766. [CrossRef]

53. McCaffrey, B.J. Purely Buoyant Diffusion Flames: Some Experimental Results; National Bureau of Standards: Washington, DC, USA, 1979; pp. 10-25.

54. Cox, G.; Chitty, R. Some source-dependent effects of unbounded fires. Combust. Flame 1985, 60, 219-232. [CrossRef]

55. Huang, Q.; Lu, S.; Liu, X.; Zheng, K.; Xu, D.; Liu, C. Experimental thermal hazard investigation on carbonate electrolytes using a cone calorimeter. Case Stud. Therm. Eng. 2021, 25, 100912. [CrossRef] 
56. Yuasa, S.; Isoda, H. Ignition and combustion of small boron lumps in an oxygen stream. Combust. Flame 1991, 86, $216-222$. [CrossRef]

57. Liu, J.; He, Y.; Zhou, Z.; Yuen, R.; Wang, J. Investigation of enclosure effect of pressure chamber on the burning behavior of a hydrocarbon fuel. Appl. Therm. Eng. 2016, 101, 202-216. [CrossRef]

58. ISO9705-1:2016(E). In Reaction to Fire Tests-Room Corner Test for Wall and Ceiling Lining Products; International Standard; ISO: Geneva, Switzerland, 2016. 